болезни сердца. Статины помимо снижения уровня холестерина могут оказывать антитромбогенный и антиоксидантный эффекты, замедлять накопление в мозге бета-амилоида. Улучшение кровообращения в системе мелких мозговых сосудов может быть обеспечено с помощью препаратов, улучшающих функцию эндотелия (периндоприл, статины), средств, улучшающих микроциркуляцию (например, пентоксифиллин), а также мерами, направленными на уменьшение вязкости крови и улучшение венозного оттока. При высоком уровне гомоцистеина показано назначение фолиевой кислоты, витаминов $\mathrm{B}_{6}$ и $\mathrm{B}_{12}$. Необходима адекватная коррекция сопутствующей соматической патологии, в частности, сердечной и дыхательной недостаточности, гипотиреоза и т. д. [9, 19-22].

\section{Заключение}

Таким образом, представленный краткий обзор литературы позволяет говорить о целесообразности направленного исследования когнитивных нарушений у пациентов с сосудистыми заболеваниями головного мозга. Более глубокое изучение вопросов когнитивной сферы, диагностики и выявления факторов риска развития деменции, а также оценки существующих методов лечения с целью дальнейшей разработки методик реабилитации и ведения пациентов с сосудистыми заболеваниями головного мозга является одним из самых приоритетных и актуальных направлений современной ангионеврологии.

\section{БИБЛИОГРАФИЧЕСКИЙ СПИСОК}

1. Когнитивные функции и качество жизни пациентов с инфарктом мозга: науч. изд. / В. Я. Латышева [и др.]. - М.: Интеграция, 2013. - $170 \mathrm{c.}$

2. Когнитивные нарушения в неврологической практике: науч.-практ. пособие / В. В. Евстигнеев [и др.]; под общ. ред. проф. В. В. Евстигнеева. - Минск: Белпринт, 2009. - 224 с.

3. Яхно, Н. Н. Легкие когнитивные нарушения в пожилом возрасте / Н. Н. Яхно, В. В. Захаров // Неврол. журн. - 2004. — № 1. — С. 4-8.
4. Эпидемиология сосудистых заболеваний головного мозга / А. А. Скоромец [и др.] // Мир медицины. - 1998. - № 9-10. - С. 98.

5. Hachinski, $V$. Vascular dementia: diagnostic criteria for research studies / V. Hachinski, J. V. Bowler // Neurology. — 1993. № 43. - P. 2159-2160.

6. Prevalence and outcomes of vascular cognitive impairment / K. Rockwood [et al.] // Neurology. — 2000. — № 54. — P. 447-451.

7. Верещагин, Н. В. Инсульт. Принципы диагностики, лечения и профилактики / Н. В. Верещагин; под ред. Н. В. Верещагина, М. А. Пирадова, 3. А. Суслиной. - М., 2002. - 208 с.

8. Болезни нервной системы: рук-во для врачей / А. И. Аверочкин [и др.]; под ред. Н. Н. Яхно, Д. Р. Штульмана. - 3-е изд. М.: Медицина, 2005. - Т. 1. - 743 с.

9. Яхно, Н. Н. Сосудистые когнитивные расстройства / Н. Н. Яхно, В. В. Захаров // РМЖ. - 2005.- Т. 13, № 12. - С. 789-793.

10. Яхно, Н. Н. Когнитивные расстройства в неврологической практике / Н. Н. Яхно // Неврол. журн. - 2006. - Прил. 1. - С. 4-12.

11. Subcortical ischemic vascular dementia/G. C. Roman [et al.] // Lancet Neurology. — 2002. — № 1. - P. 426-436.

12. Яхно, Н. Н. Сопоставление клинических и МРТ-данных при дисцикуляторной энцефалопатии / Н. Н. Яхно, О. С. Левин, И. В. Дамулин // Неврол. журн. - 2001. - № 3. - С. 10-19.

13. Захаров, В. В. Нарушения памяти / В. В. Захаров, Н. Н. Яхно. М.: ГеотарМед, 2003. - 158 с.

14. Пономарев, В. В. Нейродегенеративные заболевания / В. В. Пономарев. - СПб.: ФОЛИАНТ, 2013. - 200 с.

15. Левин, O. С. Гетерогенность умеренного когнитивного расстройства: диагностические и терапевтические аспекты / О. С. Левин, Л. В. Голубева // Консилиум. - 2006. - № 12. - С. 106-110.

16. NINDS and Canadian Stroke Network Vascular Cognitive Impairment Harmonization Standards / V. C. Hachinski [et al.] // Stroke. - 2006. - № 37. - P. 2220-2241.

17. Vascular cognitive impairment / J. T. O'Brien [et al.] // Lancet Neurology. - 2003. - № 2. - P. 89-98.

18. Hachinski, $V$. C. Multi-infarct dementia: a cause of mental deterioration in the elderly / V. C. Hachinski, N. A. Lassen, Y. Marshall // Lancet. - 1974. - № 2. - P. 207.

19. Левин, О. С. Подходы к диагностике и лечению когнитивных нарушений при дисциркуляторной энцефалопатии / О. С. Левин // Трудный пациент. - 2009. — № 2. - С. 10-19.

20. Клигуненко, Е. Н. Нейропротекция: настоящее и будущее / Е. Н. Клигуненко, Е. А. Емельянова // Нейронауки: теоретичні та клінічні аспекти. - 2008. - Т. 4, № 1. - С. 75-81.

21. Нейропротекция: модели, механизмы, терапия / под ред. М. Бэра; пер. с англ.; под ред. В. П. Зыкова, П. Р. Камчатнова. - М.: БИНОМ. Лаборатория знаний, 2011. - 429 с.

22. Островая, Т. В. Церебропротекция в аспекте доказательной медицины / Т. В. Островая, В. И. Черний // Медицина неотложных состояний. - 2007. - № 2 (9). - С. 48-52.

Поступила 30.06.2014

\title{
УДК 616-008.9:613.25 ОЖИРЕНИЕ: СОВРЕМЕННЫЙ ВЗГЛЯД НА ПРОБЛЕМУ (лекция, часть II)
}

\section{Н. М. Турченко, С. Ю. Турченко \\ Гомельская областная клиническая больница Гомельский государственный медицинский университет}

Ожирение - хроническое многофакторное гетерогенное заболевание, которое характеризуется избыточным накоплением жировой ткани в организме (у мужчин - не менее $20 \%$, у женщин - $25 \%$ массы тела, индекс массы тела (ИМТ) более 25-30). Ожирение можно также охарактеризовать как нарушение обмена веществ у лиц с генетической предрасположенностью, приводящие к избыточному отложению жира в организме, увеличение массы тела более $10 \%$ в сравнении с физиологической нормой и может сопровождаться жировой дистрофией внутренних органов - сердца, печени, почек.

Ключевые слова: ожирение, факторы развития, патогенез, принципы терапии.

\section{OBESITY: MODERN POINT OF VIEW ON THE PROBLEM (lecture, part II) \\ N. M. Turchenko, S. Yu. Turchenko \\ Gomel Regional Clinical Hospital Gomel State Medical University}

Obesity is a chronic multifactorial heterogeneous disease characterized by excessive accumulation of body fat (in men - at least $20 \%$ and in women - $25 \%$ of body weight, body mass index (BMI) is more than 25-30). Obe- 
sity can also be described as a metabolic disorder in individuals with genetic predisposition leading to excessive deposition of fat in the body weight, overweight being more than $10 \%$ compared to the physiological norm, and may be accompanied by fatty degeneration of internal organs - heart, liver, kidneys.

Key words: obesity, development factors, pathogenesis, treatment principles.

\section{Клиническая картина}

Ожирение, независимо от причин, сопровождается вторичными изменениями во многих внутренних органах. У больных с ожирением появляется склонность к вторичным воспалительным процессам (фолликулиты, упорный фурункулез, флегмоны, микозные поражения кожи и ее придатков, экземы). У многих больных эти проявления сочетаются с симптомами нарушения трофики кожи (цианоз, выпадение волос, повышенная ломкость ногтей). Особого внимания заслуживает появление на теле больных полос растяжения. В начале они имеют темно-розовый цвет, впоследствии приобретают серо-желтую окраску (исключение составляют багровоцианотичные стрии, появляющиеся на теле при гиперкортицизме). Расположение полос обычно симметричное, в местах максимального скопления жировой ткани (живот, бедра, ягодицы, грудные железы). Для появления полос растяжения имеет значение механический фактор перерастяжения кожи и трофический фактор, обуславливающий нарушения белкового обмена (снижается образование коллагена). В результате снижения эластичности кожи и ослабления мышечного тонуса могут появляться грыжевые выпячивания (пупочные, паховые, бедренные), расхождение прямых мышц живота. Отмечаются изменения сосудистой системы кожи, которые проявляются в виде телеангиоэктазий. Характерным признаком ожирения является лимфостаз нижних конечностей [7, 9, 11, 14].

Избыточная масса тела оказывает чрезмерную нагрузку на опорно-двигательный аппарат с развитием в нем различных дегенеративных процессов. Характерные изменения костно-суставной системы следующие:

- дегенеративные изменения в суставах позвоночника и конечностей с развитием деформирующего спондилеза или остеоартроза крупных суставов;

- системный остеопороз;

- вальгусная деформация стоп и коленей, плоскостопие.

Свойственными ожирению нарушениями являются изменения дыхательной системы. Уже на ранних стадиях появляется одышка после незначительной физической нагрузки вследствие изменения подвижности диафрагмы и расширяемости самой грудной клетки. На этом фоне у больных появляется сонливость, периодическое поверхностное дыхание, цианоз, вторичная эритремия, гипертрофия правого желудочка и прогрессирующее развитие недостаточности кровообращения. Нарушение легочной вентиляции на фоне сниже- ния неспецифической резистентности часто сопровождается развитием длительно протекающих воспалительных процессов.

Изменения функции почек при ожирении носят обратимый характер и проявляются в виде полиурии и в незначительном увеличении СКФ, гиперуринемии. Типичным для ожирения является развитие нефролитиаза (чаще уратного или оксалатного) с присоединением вторичной инфекции в виде пиелонефрита, цистита, уретрита.

Сердечно-сосудистые поражения у больных с ожирением встречаются в виде ИБС, системного атеросклероза, миокардиодистрофии, АГ. При миокардиодистрофии увеличивается количество жировой ткани вне перикарда, между волокнами, в самих кардиомиоцитах. Увеличение массы тела сопровождается его гипертрофией. Обильная васкуляризация тканей приводит к повышенному потреблению кислорода, что требует компенсаторного увеличения минутного объема сердца. Указанные гемодинамические изменения сопровождаются утомляемостью, учащенным сердцебиением, одышкой, стенокардитическими болями в области сердца. При перкуссии определяется увеличение относительной сердечной тупости, преимущественно за счет увеличения левых отделов сердца. Аускультативно - тоны сердца приглушены.

В развитии АГ участвуют многие факторы: конституциональные, увеличение систолического выброса сердца, изменение функции коры надпочечников; механический фактор, обусловленный увеличением плеча; избыточный объем жидкости (увеличение ЦК). Гиперлипидемия, развивающаяся на фоне ожирения, способствует прогрессированию атеросклеротических процессов. Наиболее частыми локализациями являются коронарные, мозговые и почечные артерии. В результате наличия на фоне ожирения подавляющего большинства из факторов риска развития ИБС (гиподинамия, АГ, нарушение толерантности к глюкозе, гиперкоагуляция) она развивается в более молодом возрасте и имеет прогрессирующее течение. Именно эти поражения являются основной причиной летальности при ожирении. Гиперкоагуляционный синдром определяется повышением уровня протромбина, увеличением адгезии тромбоцитов, снижением фибринолитической активности крови. В результате развития гиперкоагуляции повышается склонность у больных к образованию внутрисосудистых тромбов или эмболов [9, 10, 12].

Четкие изменения прослеживаются со стороны печени и ЖВП. При прогрессирующем ожире- 
нии увеличивается масса тела за счет ее жировой инфильтрации, отмечается отложение жира в капсуле печени, в РЭС, прогрессирующее снижение в ней гликогена. Ожирение является предрасполагающим к развитию ЖКБ, холецистита, дискинезии ЖВП. В основе этих процессов лежат дискинезия, способствующая застою желчи. ЖКБ протекает с очень скудной симптоматикой и поэтому часто диагностируется с опозданием [1, 4, 7, 9].

Различные клинические формы панкреатита чаще встречаются на фоне ожирения. При этом отмечается снижение активности внешнесекреторной части (со снижением активности и количества амилазы, липазы, трипсина) и нарушением ее внутрисекреторной функции с развитием нарушенной толерантности к глюкозе или сахарного диабета 2 типа $[4,7,8,9]$.

Нарушение половой функции проявляется на фоне II-III степеней ожирения и выражается у мужчин в виде нарушений потенции, а у женщин - в виде дисменореи и нарушений фертильности $[4,6,8,9]$.

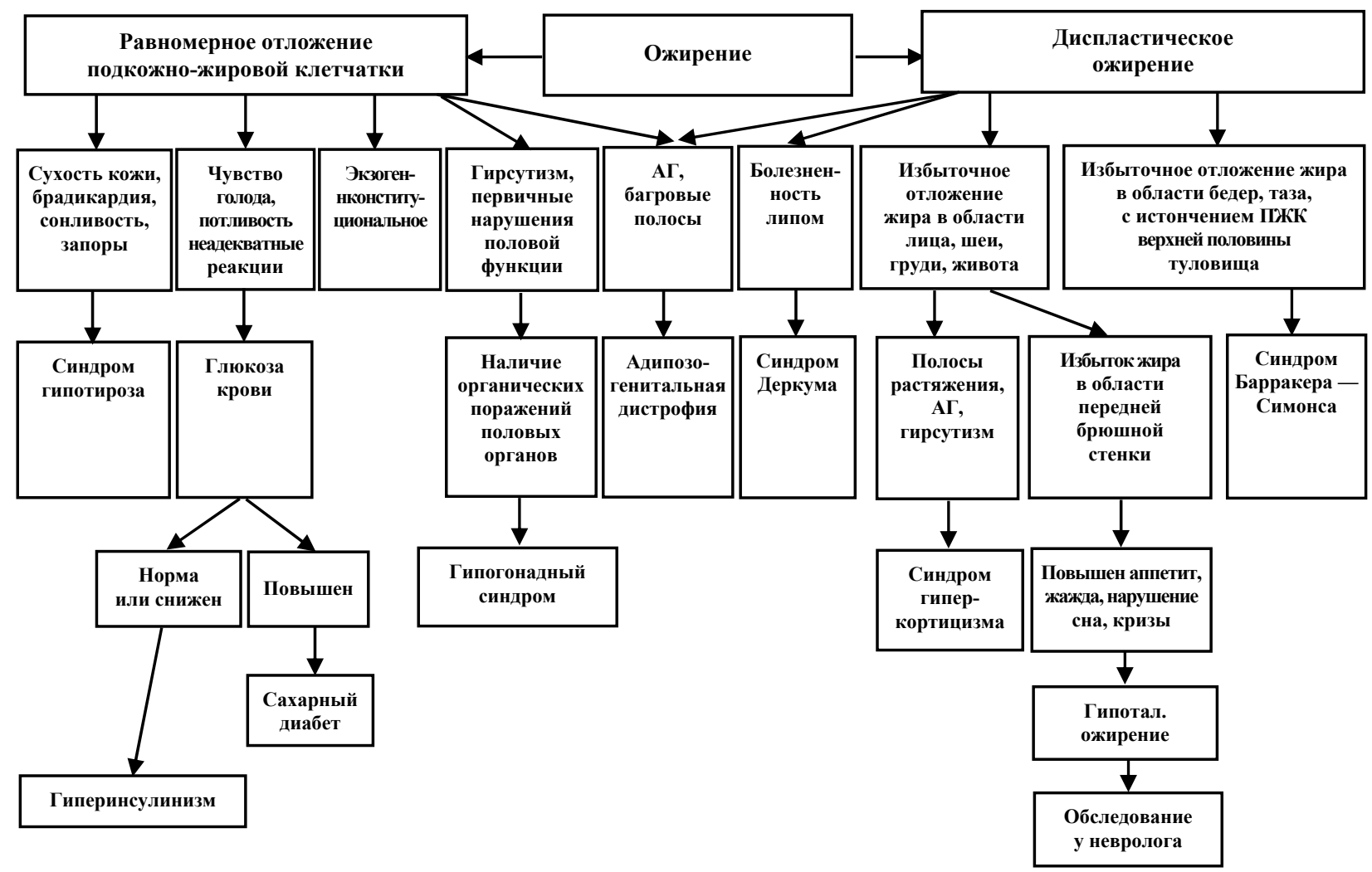

Рисунок 1 - Схема дифференциальной диагностики заболеваний, сопровождающихся ожирением

\section{Лечение ожсиения}

Методы лечения ожирения:

1. Немедикаментозные (обучение больных, рациональное сбалансированное питание, повышение физической активности, изменение образа жизни).

2. Медикаментозные.

3. Хирургические.

Тактика лечения выбирается в зависимости от ИМТ и сопутствующих факторов риска $[10,12,13,14]$ :

- ИМТ 18,5-24,9 (без факторов риска) здоровый образ жизни, поддержание нормальной массы тела.

- ИМТ 18,5-24,9 (с наличием факторов риска): при увеличении ОТ - снижение массы тела, при наличии гиперлипидемии, АГ, нарушении углеводного обмена - гиполипидемическая диета, диета с ограничением соли и рафинированных сахаров, физическая нагрузка, прекращение курения.
- ИМТ 25,0-29,9 (без факторов риска) гипокалорийное питание, увеличение физической активности, поддержание массы тела.

- ИМТ 25,0-29,9 (с наличием факторов риска) - гипокалорийное питание, увеличение физической активности, снижение факторов риска. При отсутствии снижения факторов риска в течение 3 месяцев необходимо снизить массу тела на 5-10 кг за 6 месяцев на фоне низкокалорийного суточного рациона. При отсутствии эффекта - медикаментозная терапия.

- ИМТ 30,0-34,9 (без факторов риска) снижение массы тела на 5-10\%. Медикаментозная терапия.

- ИМТ 30,0-34,9 (с наличием факторов риска) - снижение массы тела на 5-10\%. Комбинированное лечение: низкокалорийное питание, физическая активность, медикаментозная терапия. 
- ИМТ 35,0-39,9 (с высоким риском развития сопутствующих заболеваний) - комплексное лечение: низкокалорийное питание, физическая активность, медикаментозная терапия, снижение массы тела более чем на $10 \%$. При неэффективности консервативных методов - хирургическое вмешательство.

- ИМТ 35,0-39,9 (с сопутствующими заболеваниями) - хирургическое лечение.

- ИМТ 40,0 и более - хирургическое лечение.

Питание

В основе лежит низкокалорийное питание (от 800 до 1500 ккал/сут) с учетом индивидуальных пищевых пристрастий больного, его образа жизни, возраста, пола, экономических возможностей в сочетании с увеличением физической активности. Суточная калорийность пищи должна быть ниже энергетических затрат. Низкокалорийная диета предполагает ограничение приема углеводов в виде олигосахаридов, сладостей, жиров животного происхождения, соли и жидкости, включение в рацион пищевых волокон, частое дробное питание (5-6 раз в день). Редуцированные диеты, содержащие 500-800 ккал с резким ограничением углеводов, повышенным содержанием белка или жира, не имеют преимуществ перед рациональной низкокалорийной диетой и могут назначаться на короткое время в стационаре. Полное голодание с употреблением минеральных вод признается недостаточно обоснованным в связи с доказанным отсутствием эффекта и опасностью развития осложнений (кетоацидоз, диспепсические расстройства, коллапс, срывы сердечного ритма, ишемия миокар- да). Установлено, что у людей, склонных к ожирению, избыточный жир накапливается легче, а окисляется труднее, чем у лиц с нормальной массой тела. Ограничение содержания жиров менее $30 \%$ от суточной калорийности приводит к дефициту обмена жиров и возрастанию расхода энергии. Для длительного поддержания достигнутого уменьшения массы тела диета с низким содержанием жира должна стать частью образа жизни лиц, склонных к ожирению. В питание необходимо включать большое количество продуктов, богатых сложными углеводами и растительными волокнами, что уменьшает чувство голода и облегчает соблюдение диеты. Количество углеводов должно составлять 55-60\% суточной калорийности. Следует ограничить или исключить вкусовые приправы и экстрактивные вещества. Обязательным является употребление растительных жиров (таблица 1) [10,12].

Кроме основной диеты № 8 необходимо 1 2 раза в неделю проводить разгрузочные дни:

- Рисово-яблочный день: больной получает 3 порции рисовой каши (25 г риса на 150 мл молока) и 800 г сырых или печеных яблок.

- Творожно-простоквашные дни (3 порции творога и 3 порции простокваши по 200-300 мл).

Натуральные соки (100\%):

$\begin{array}{lcc}\text { Яблочный } & 100 \text { мл } & 45 \text { ккал } \\ \text { Грейпфруктовый } & 130 \text { мл } & 50 \text { ккал } \\ \text { Апельсиновый } & 110 \text { мл } & 50 \text { ккал } \\ \text { Виноградный } & 70 \text { мл } & 50 \text { ккал } \\ \text { Лимонный } & 150 \text { мл } & 55 \text { ккал } \\ \text { Морковный } & 200 \text { мл } & 55 \text { ккал } \\ \text { Томатный } & 300 \text { мл } & 60 \text { ккал }\end{array}$

Таблица 1 - Перечень продуктов для питания лиц, страдающих ожирением

\begin{tabular}{|c|c|c|c|}
\hline Продукты & Рекомендуемые продукты & $\begin{array}{c}\text { Продукты, которые следует } \\
\text { употреблять умеренно }\end{array}$ & $\begin{array}{c}\text { Пища, нежелательная } \\
\text { для употребления }\end{array}$ \\
\hline Мучные & $\begin{array}{l}\text { Хлеб с отрубями, макаронные из- } \\
\text { делия, сухари, овсяная каша, рис }\end{array}$ & & Булочки из слоеного теста \\
\hline $\begin{array}{l}\text { Овощи, } \\
\text { салаты, } \\
\text { фрукты }\end{array}$ & $\begin{array}{l}\text { Все свежие и замороженные ово- } \\
\text { щи, частично бобовые: фасоль, } \\
\text { сушеная фасоль, чечевица, моло- } \\
\text { дой горох, сладкая кукуруза, от- } \\
\text { варной картофель, картофель в } \\
\text { мундире, все свежие и сушеные } \\
\text { фрукты, консервированные фрук- } \\
\text { ты без сахара }\end{array}$ & $\begin{array}{l}\text { Жареный картофель, кар- } \\
\text { тофельные чипсы, приго- } \\
\text { товленные на растительном } \\
\text { масле }\end{array}$ & $\begin{array}{l}\text { Жареный картофель, овощи } \\
\text { или рис, приготовленные на } \\
\text { животных жирах, чипсы, } \\
\text { приготовленные в духовке, } \\
\text { хрустящий картофель, кар- } \\
\text { тофельные чипсы, соленые } \\
\text { консервированные овощи }\end{array}$ \\
\hline Приправы & Перец, травы, горчица, специи & $\begin{array}{l}\text { Салатные приправы с низ- } \\
\text { ким содержанием жиров }\end{array}$ & $\begin{array}{l}\text { Сливки, майонез, дополни- } \\
\text { тельное подсаливание пищи }\end{array}$ \\
\hline Супы & Рыбный, овощной & & Жирные супы, суп со сметаной \\
\hline Молочные & $\begin{array}{l}\text { Обезжиренное молоко, йогурт } \\
\text { с очень низким содержанием } \\
\text { жиров. Сыры с низким содер- } \\
\text { жанием жира (до } 17 \text { \%), не- } \\
\text { жирный творог, брынза }\end{array}$ & $\begin{array}{l}\text { Полужирное молоко, йо- } \\
\text { гурт с низким содержанием } \\
\text { жира, два яйца в неделю, } \\
\text { сыры с низким содержани- } \\
\text { ем жира (до } 30 \text { \%) }\end{array}$ & $\begin{array}{l}\text { Цельное молоко, жирные } \\
\text { сыры, сгущенное молоко, } \\
\text { жирный йогурт, сливки }\end{array}$ \\
\hline Рыба & $\begin{array}{l}\text { Любые сорта белой и жирной } \\
\text { рыбы (отварной, жареной, коп- } \\
\text { ченой) без кожи }\end{array}$ & $\begin{array}{l}\text { Рыба, жаренная на расти- } \\
\text { тельном масле }\end{array}$ & $\begin{array}{l}\text { Икра, угорь, рыба, приго- } \\
\text { товленная на неизвестном } \\
\text { или животном жире }\end{array}$ \\
\hline
\end{tabular}


Окончание таблицы 1

\begin{tabular}{|c|c|c|c|}
\hline Продукты & Рекомендуемые продукты & $\begin{array}{c}\text { Продукты, которые следует } \\
\text { употреблять умеренно }\end{array}$ & $\begin{array}{c}\text { Пища, нежелательная } \\
\text { для употребления }\end{array}$ \\
\hline Дары моря & Мидии, устрицы, гребешки, омары & Креветки, кальмары & \\
\hline Мясо & $\begin{array}{l}\text { Индейка, курица (без кожицы), } \\
\text { крольчатина, телятина, дичь, } \\
\text { мясо молодого ягненка }\end{array}$ & $\begin{array}{l}\text { Постная говядина, ветчина, } \\
\text { телячья или куриная колба- } \\
\text { са, печень ( } 2 \text { раза в месяц) }\end{array}$ & $\begin{array}{l}\text { Утка, гусь, пироги с мясом, } \\
\text { салями, паштеты, бекон, со- } \\
\text { сиски, колбасы, всевозмож- } \\
\text { ное жирное мясо, кожица } \\
\text { домашней птицы }\end{array}$ \\
\hline Жиры & & $\begin{array}{l}\text { Ненасыщенные масла: олив- } \\
\text { ковое, кукурузное, подсол- } \\
\text { нечное, маргарины на осно- } \\
\text { ве этих масел, особенно мас- } \\
\text { ло пониженной жирности }\end{array}$ & $\begin{array}{l}\text { Масло, свиное сало, жир, } \\
\text { нутряное сало }\end{array}$ \\
\hline Десерты & Фруктовый салат & $\begin{array}{l}\text { Желе, приготовленное на не- } \\
\text { жирном молоке, безе, пудинги }\end{array}$ & $\begin{array}{l}\text { Мороженое, соусы, приго- } \\
\text { товленные из сливок или } \\
\text { сливочного масла, пудинг }\end{array}$ \\
\hline Выпечка & & $\begin{array}{l}\text { Кондитерские изделия, би- } \\
\text { сквиты, приготовленные на } \\
\text { ненасыщенных маргаринах } \\
\text { и маслах }\end{array}$ & $\begin{array}{l}\text { Пирожные, пироги, сладо- } \\
\text { сти, бисквиты }\end{array}$ \\
\hline Сладости & & $\begin{array}{l}\text { Марципан, восточные сла- } \\
\text { дости, халва, нуга, карамель }\end{array}$ & $\begin{array}{l}\text { Шоколад, ирис, помадка, ба- } \\
\text { тончики с кокосовым орехом }\end{array}$ \\
\hline Орехи & & $\begin{array}{l}\text { Грецкие орехи, фундук, арахис, } \\
\text { миндаль, каштан, фисташки }\end{array}$ & Кокос, соленые орехи \\
\hline Напитки & $\begin{array}{l}\text { Чай, растворимый или отфильт- } \\
\text { рованный кофе, минеральная во- } \\
\text { да, низкокалорийные напитки }\end{array}$ & $\begin{array}{l}\text { Алкоголь, низкокалорийные } \\
\text { шоколадные напитки }\end{array}$ & $\begin{array}{l}\text { Шоколадные напитки, ки- } \\
\text { пяченный кофе, кофе по- } \\
\text { ирландски }\end{array}$ \\
\hline
\end{tabular}

Режим физической активности и лечебной физкультуры

Непременное условие эффективного лечения - физические упражнения с целью повышения основного обмена за счет усиления мобилизации и метаболизма жира, сохранения и даже усиления синтеза белка в скелетной мускулатуре при одновременном замедлении его разрушения, усиления эффективности действия инсулина. Физические упражнения должны быть регулярными, достаточно интенсивными и соответствовать индивидуальным особенностям организма (возраст, пол, наличие сопутствующих заболеваний и т. д.). На начальных этапах эффективность лечения может быть достигнута, если пациент выполняет нагрузку умеренной интенсивности в течение 30 минут в день не менее 5 раз в неделю. Необходимо, чтобы пациент испытал достаточное напряжение со стороны работы сердца и органов дыхания. Частота сердечных сокращений должна приблизиться к индивидуальной целевой зоне. Она составляет $50-75 \%$ от максимальной частоты сердечных сокращений (таблица 2) [6, 7, 10, 12].

Таблица 2 - Целевая зона пульса в зависимости от возраста

\begin{tabular}{|l|c|c|}
\hline \multicolumn{1}{|c|}{ Возраст, лет } & $\begin{array}{c}\text { Целевая зона пульса - } \\
50-75 \% \text { ударов в минуту }\end{array}$ & $\begin{array}{c}\text { Возрастной максимум пульса }- \\
100 \text { \% ударов в минуту }\end{array}$ \\
\hline $20-30$ & $98-146$ & 195 \\
\hline $31-40$ & $93-138$ & 185 \\
\hline $41-50$ & $88-131$ & 175 \\
\hline $51-60$ & $83-123$ & 165 \\
\hline Более 61 & $78-116$ & 155 \\
\hline
\end{tabular}

Если частота сердечных сокращений ниже целевой зоны, значит, величина нагрузки недостаточна, а если превышает - нагрузку необходимо уменьшить, чтобы избежать осложнений, вызванных переутомлением. Самым доступным и эффективным видом физической нагрузки является ходьба. Начинают ходьбу с
10-15 минут в день, постепенно увеличивая продолжительность до 30-40 минут. Самое главное, чтобы прогулки были регулярными.

\section{Медикаментозные методы}

По механизму действия препараты для лечения ожирения можно разделить на 3 группы $[9,10,14]:$ 
I. Снижающие потребление пищи: амфетамины (метамфетамин, амфетамин, фепранон), фенфлурамин (минифаж), дексфенфлурамин (изолипан), сибутрамин (меридиа), флюоксетин (прозак), фенилпропаноламин (тримекс).

II. Увеличивающие расход энергии: термогенные симпатомиметики, эфедрин, кофеин, сибутрамин, тиреоидные гормоны.

III. Уменьшающие всасывание питательных веществ: орлистат (ксеникал), акарбоза (глюкобай), метформин (сиофор).

Фепранон - обладает анорексигенным действием, оказывает слабое возбуждающее действие на ЦНС. Выпускается в таблетках по 0,025 г. Принимают по 1 таблетке за 30-60 минут до еды в течение 4-5 недель. Повторные курсы через 1 месяц.

Фенфлюрамин - ингибирует центр аппетита и повышает активность центра насыщения; уменьшает всасывание жиров в кишечнике; гипотензивное и седативное действие; уменьшение массы тела.

Тиреоидные гормоны - усиливают метаболические процессы и липолиз, увеличивают потребление кислорода, уменьшают де- понирование энергии и способствуют превращению ее в тепло. Под влиянием тиреоидных гормонов усиливается мобилизация жира из депо, выведение воды из организма. Противопоказанием к применению тиреоидных препаратов являются: АГ, ИБС, СД. Рекомендуются малые дозы тиреоидных гормонов: тироксин - по 25-50 мкг/сут, трийодтиронин по 12,5-25 мкг/сут.

Бигуаниды имеют следующие механизмы действия (рисунок 2):

• усиливают поглощение глюкозы мышцами;

- замедляют скорость абсорбции глюкозы из кишечника, что улучшает биологический эффект инсулина;

- увеличивают количество рецепторов к инсулину в периферических тканях;

- стимулируют липолиз и тормозят липогенез, способствуют уменьшению массы тела;

- усиливают анаэробный липолиз;

- анорексигенное действие;

- активация фибринолиза;

- уменьшают содержание холестерина и атерогенных липопротеидов в крови.

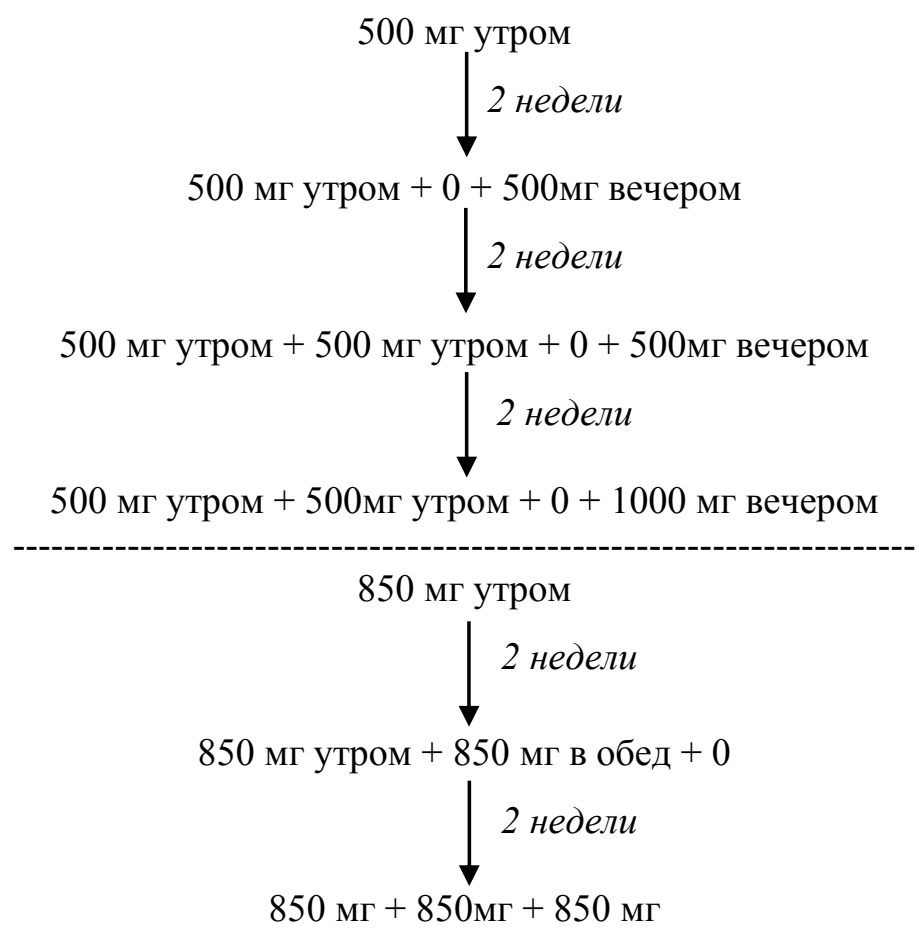

Рисунок 2 - Принцип назначения бигуанидов

Хирургические методы лечения

Хирургические методы применяются при ожирении высокой степени, когда использование других методов лечения оказалось безуспешным. Существует несколько вариантов хирургического лечения:

- удаление ПЖК;

- отсасывание жировых отложений;

- формирование малого желудка;

• желудочный обход и др.
В среднем пациенты могут терять более 50-80 \% избыточной массы в течение последующих 12-18 месяцев. Все больные, получившие хирургическое лечение, должны выполнять программу по снижению массы тела и наблюдаться в течение первых двух лет у хирурга не реже 1 раза в квартал, а затем ежегодно.

Ведение дневника контроля за питанием и объективными параметрами пациента (ИМТ, масса тела, ОТ, ОБ/ОТ, АД, уровень гликемии, липиды 
крови и др.) окажет хорошую помощь в выполнении программы по снижению массы тела [9, 10, 14].

\section{Профилактика ожирения}

Профилактику ожирения целесообразно проводить при семейной предрасположенности к его развитию, при предрасположенности к развитию заболеваний, сопутствующих ожирению.

Ожирение - это хроническое заболевание и его лечение должно быть пожизненным. В настоящее время ведение больных, основанное на физиологических принципах соблюдения диеты с умеренным ограничением жира и большим содержанием углеводов, с адекватной физической нагрузкой, с дополнительной медикаментозной терапией по показаниям, дает шанс на долговременный успех $[1,4,9,10,12]$.

\section{БИБЛИОГРАФИЧЕСКИЙ СПИСОК}

1. Шутова, В. И. Ожирение, или синдром избыточной массы тела / В. И. Шутова, Л. И. Данилова // Медицинские новости. 2004. — № 7. - С. 41-47.

2. Аметов, А. С. Ожирение и сердечно-сосудистые заболевания / А. С. Аметов, Т. Ю. Демидова, А. Л. Целиковская // Терапевт. арх. - 2001. - Т. 73, № 8. - С. 66-69.

3. Вербовая, Н. Е. Ожирение и соматотропный гормон: причинно-следственные отношения / Н. Е. Вербовая, С. В. Булгакова // Проблемы эндокринологии. - 2001. - № 3. - С. $44-47$.
4. Глюкозоиндуцированный термогенез у лиц с ожирением / Н. Т. Старкова [и др.] // Пробл. эндокринологии. - 2004. - Т. 50, № 4. - C. 16-18.

5. Milewicz, A. Perimenopausal obesity / A. Milewicz, B. Bidzińska, A. Sidorowicz // Gynecol Endocrinol. — 1996. — № 10(4). - P. 285-291. Review PMID: 8908531 [PubMed - indexed for MEDLINE] (Проблемы эндокринологии. - 1998. - № 1. - С. 52-53).

6. Краснов, В. В. Масса тела больного ишемической болезнью сердца: спорные и нерешенные вопросы / В. В. Краснов // Кардиология. - 2002. - № 9. - С. 69-71.

7. Аметов, А. С. Принципы питания больных ожирением / А. С. Аметов // Диабет. Образ жизни. - 1997. - № 7. - С. 28-30.

8. Вознесенская, Т. Г. Ожирение и метаболизм / Т. Г. Вознесенская // Расстройства пищевого поведения при ожирении и их коррекция. - 2004. - № 2. - С. 25-29.

9. Справочник по клинической фармакологии / Е. А. Холодова [и др.]; под ред. Е. А. Холодовой. - Минск: Беларусь, 1998. - С. 259-277.

10. Окороков, А. Н. Лечение болезней внутренних органов / А. Н. Окороков. - Минск: Выш. шк., 1996. - Т. 2. - С. 455-472.

11. Балаболкин, М. И. Дифференциальная диагностика и лечение эндокринных заболеваний / М. И. Балаболкин, Е. М. Клебанова, В. М. Креминская. - М.: Медицина, 2002. - 751 с.

12. Клиорин, А. И. Ожирение в детском возрасте / А. И. Клиорин. - Л.: Медицина, 1989. - 256 с.

13. Дедов, И. И. Обучение больных ожирением (программа) / И. И. Дедов, С. А. Бутрова, Л. В. Савельева. - М., 2002. - 52 с.

14. Lavin, N. Manual of Endocrinology and Metabolism / N. Lavin. - 2-nd ed. - Boston: Little, Brown and Company, 1994. P. 38, 66, 138, 154, 357, 384, 387.

15. Данилова, Л. И. Метаболический синдром: диагностические критерии, лечебные протоколы: учеб.-метод. пособие / Л. И. Данилова, Н. В. Мурашко. - Минск: БелМАПО, 2005. - 26 с.

Поступила 15.05.2014

\title{
УДК 616.126-002-07-08 \\ ИНФЕКЦИОННЫЙ ЭНДОКАРДИТ: ЭВОЛЮЦИЯ ВОЗБУДИТЕЛЕЙ И КЛИНИКИ, ДИАГНОСТИКА, ТАКТИКА И СТРАТЕГИЯ ЛЕЧЕНИЯ
}

\author{
Н. М. Ведерко, Е. Г. Малаева, А. Н. Цырульникова, В. А. Грищенко
}

Гомельский государственный медицинский университет

В статье наиболее полно отражено развитие инфекционного эндокардита на протяжении последних 30 лет. Прослежена эволюция основных возбудителей, представлены критерии диагностики инфекционного эндокардита, даны рекомендации по этиотропной антибактериальной терапии и хирургическому лечению.

Ключевые слова: инфекционный эндокардит, протезирование, консервативное лечение, хирургическое лечение, летальность.

\section{INFECTIOUS ENDOCARDITIS: EVOLUTION OF CAUSATIVE AGENTS AND CLINICAL PICTURE, DIAGNOSIS, TACTICS AND THERAPY}

\author{
N. M. Vederko, E. G. Malayeva, A. N. Tsyrulnikova, V. A. Grischenko \\ Gomel State Medical University
}

This article reflects the development of infectious endocarditis over the last 30 years. The evolution of the basic causative agents has been retraced, the diagnosis criteria of infectious endocarditis have been presented, some advice on the etiotropic antibacterial therapy and surgery has been given.

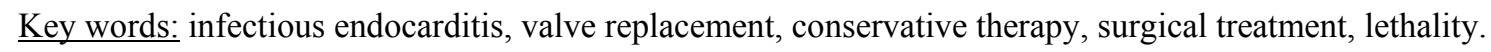

Инфекционный эндокардит (ИЭ) представляет собой одну из ведущих проблем современной клинической медицины и практического здравоохранения. Наблюдается неуклонный рост числа больных этим тяжелым заболеванием с неблагоприятным прогнозом и непредсказуемостью результатов лечения [1]. Встречаемость этой патологии составляет от 2 до 3,8-6,5 \% на 100 тыс. населения [2]. За последние 30 лет частота ИЭ возросла в 3 раза, и в настоящее время он является четвертой жизнеопасной инфекцией [3].

Растет удельный вес инфицирования интактных клапанов сердца - с 1,8 \% в 80-е годы, $18,7 \%$ в 90-е до 40-60 \% в 2000-е годы [4]. В 2007 г. 